\title{
Kinetics of arsenite removal by halobacteria from a highland Andean Chilean Salar
}

\author{
Díaz-Palma Paula ${ }^{1,2 *}$, Alfaro Gleny', Hengst Martha ${ }^{3}$, Pozo Patricia', Stegen Susana', Queirolo Fabrizio', \\ Rojo Gonzalo ${ }^{1}$, Silva Pedro ${ }^{1}$, Arias Diana ${ }^{1}$, Gallardo Karem ${ }^{1}$ and Contreras-Ortega Carlos ${ }^{1}$
}

\begin{abstract}
Background: The purpose of this study was to identify arsenite-oxidizing halobacteria in samples obtained from Salar de Punta Negra, II Region of Chile. Seven bacterial isolates, numbered as isolates I to VII, grown in a culture medium with 100 ppm as $\mathrm{NaAsO}_{2}$ (As (III)) were tested. Bacterial growth kinetics and the percent of arsenite removal (PAR) were performed simultaneously with the detection of an arsenite oxidase enzyme through Dot Blot analysis.

Results: An arsenite oxidase enzyme was detected in all isolates, expressed constitutively after 10 generations grown in the absence of As (III). Bacterial growth kinetics and corresponding PAR values showed significant fluctuations over time. PARs close to 100\% were shown by isolates V, VI, and VII, at different times of the bacterial growth phase; while isolate II showed PAR values around 40\%, remaining constant over time.

Conclusion: Halobacteria from Salar de Punta Negra showed promising properties as arsenite removers under control conditions, incubation time being a critical parameter.
\end{abstract}

Keywords: Arsenic, Removal, Halobacteria, Arsenite-Oxidase

\section{Background}

Arsenic is an element distributed throughout the earth's crust, with an average concentration of $2 \mathrm{mg} / \mathrm{Kg}[1,2]$. It is present as trace quantities in rocks, air, soil, and water [3]. This element can be found as a soluble species in nature due to natural weathering (mobilization) from rocks and soils, appearing in the form of oxyanions. This occurs mainly in two oxidation states, 3+ (arsenite) and $5+$ (arsenate), and less frequently as 0 (elemental arsenic) and 3- (arsine). $\mathrm{As}^{3+}$ and $\mathrm{As}^{5+}$ named as As III and As $\mathrm{V}$ from now on, respectively, are mobile in the environment, the first state being more labile and toxic for most life forms [2].

In Chile, arsenic is found in most ecosystems of the northern and central area. Geology, volcanic activity, and mining operations are responsible for the presence of arsenic concentrations in surface waters and groundwater

\footnotetext{
*Correspondence: pdiaz@ucn.cl

'Departamento de Química, Facultad de Ciencias, Universidad Católica del Norte, P.O.1280, Antofagasta, Chile

${ }^{2}$ Advanced Mining Technology Center, AMTC, Universidad de Chile, Tupper 2007, Santiago, Chile

Full list of author information is available at the end of the article
}

sources. The most extensive arsenic enrichment is located between $17^{\circ} 30^{\prime}-26^{\circ} 05^{\prime}$ south latitude and between $67^{\circ}$ $00^{\prime}$ east longitude in the Andean Highlands (over 2,000 m.a.s.l.). The Atacama Desert is located in this vast region, where concentrations of total arsenic have been reported as high as $200 \mathrm{ppm}$ (unpublished report).

Different water treatment technologies have been developed for arsenic removal. They are based on diverse processes such as coagulation, filtration, adsorption, and reverse-osmosis [4]. However, most of these technologies target As $(\mathrm{V})$, thus requiring a pre-oxidation step to change As (III) into As (V). This step is usually performed by employing powerful chemical oxidants (ozone, chlorine, or $\mathrm{H}_{2} \mathrm{O}_{2}$ ), which have different toxicity degrees [5]. Thus, the bacterial biotransformation of toxic arsenic compounds becomes a more friendly alternative for human and environmental health than chemical remediation.

The importance of microorganisms in arsenic transformation and its biogeochemical cycle has recently received much attention [6-12]. Most of the microorganisms involved in As transformation cycling live in places where, naturally or anthropogenically, the concentrations of this metalloid in its most toxic form

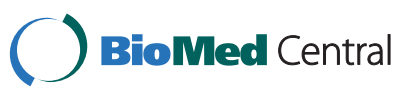


(As (III)) are high. Therefore, these microorganisms should be able to change the arsenic oxidation states by chemically transforming it in order to survive. The capability of bacterial species to transform arsenite to arsenate is due to the presence of the arsenite oxidase enzyme (AOX), which was extracted, purified, and characterized for the first time from Alcaligenes faecalis strains [6,7]. Subsequently, arsenite oxidase has been found in other bacterial strains and studied in detail (eg. Pseudomonas alcaligenes, Agrobacterium tumefaciens, Alkalilimnicola ehrlichii, Wautersia solanacearum, Acinetobacter calcoaceticus, and Enterobacter cloacae). Some bacteria gain energy from arsenite oxidation [8-10,12]; however, this activity would be limited, on exceptional grounds, to chemolithoautotrophic bacteria. On the other hand, energy gained through heterotrophic bacteria experimentally grown with arsenite has yet to be proven [10,11]. Though there is a great diversity of arsenite-oxidizer bacteria well handled under laboratory conditions, experimental evidence shows that it is dificult for these bacterial strains to adapt to field conditions, where arsenite removal is needed. In these cases the optimal strategy is the use of in-situ bioremediation, which involves growth stimulation of native bacterial flora having metabolic capabilities to biotransform arsenite. Therefore, it is desirable to search for autochthonous organisms leading to in-situ bioremediation strategies, by making site-specific studies.

A high functional diversity of extremophiles microorganisms is developed in Highland Andean ecosystems [13]. These microbial communities are adapted to high arsenic charges present in a natural form in water and in sediments, therefore it are a source of researching looking for bio-transforming the toxic arsenic species. Both spring waters and shallow hypersaline lagoons from Salar de Punta Negra, located in the Andean Highlands of Chile, are naturally enriched with arsenic, which reaches above $100 \mathrm{ppm} / \mathrm{L}$. To investigate the presence of arsenite-oxidizing halobacteria in samples obtained from this place and eventually the existence of enzyme arsenite oxidase in these bacteria, their capability to remove As (III) along with the kinetics of bacterial growth for its potential use in in-situ bioremediation strategies were evaluated. The presence of the enzyme arsenite oxidase was analyzed by using molecular techniques.

\section{Results}

Characterization of Bacteria Isolates: After $18 \mathrm{~h}$ of culture, different colonies grew on IM and CIM media plates. There were no significant differences in number and/or shape among colonies grown in either culture media (Figures 1A and 1B). Thirteen morphotypes from all the colonies were selected according to their aspect (appearance, color, shape, average diameter, and edge characteristics). They were characterized by Gram stain. All isolates corresponded to strepto-bacillus gramnegative bacteria. Additionally, microscopic analyses revealed the presence of bacteroides or long-sized nonsegmented bacteria (Figure 1C).

Based on the digestion with restriction enzymes of $16 \mathrm{~S}$ rRNA gene, the 13 isolates determined by RFLP analysis actually matched with 7 different isolates. RFLP results were used as identification criteria for these 7 isolates, by using Roman numerals from I to VII.

Arsenic and Bacterial Growth Kinetics: Figure 2 shows the fluctuation of As (III) concentration values measured in treatments (isolates I to VII) and controls, together with bacterial growth curves for each isolate. Data at $t_{8}$ are not shown in figures and tables containing arsenite values (Figures 2, 3 and Table 1) because variability among replicates was too large to be considered.

Arsenite values presented great variation during the experimental time $\left(t_{0}-t_{27}\right)$, showing arsenite reductions for all isolates as compared to the control, at the same incubation time (Figure 2, A to E). Isolates VI and VII showed reductions at all incubation times $\left(t_{0}-t_{27}\right)$; isolate $\mathrm{V}$ showed reductions up to $\mathrm{t}_{27}$; and isolate II from $t_{4}$ to $t_{27}$. Some of these measurements were close to the detection limit of the method (0.001 ppm), showing values close to zero, revealed at $6 \mathrm{~h}\left(\mathrm{t}_{6}\right)$ for isolate VI
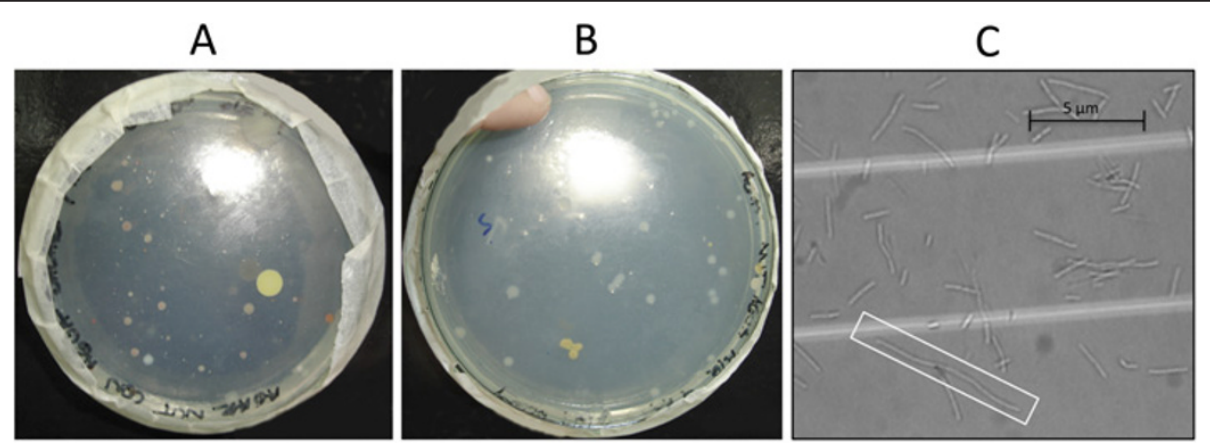

Figure 1 Morphological Characterization of Bacterial Isolates from Salar de Punta Negra. A: Colonies from G in IM Media; B: Colonies from $G_{1}$ in CIM Media, and C: Bacteroid, or non- segmented elongated bacterial cell (rectangle) present in GM/S Media. 


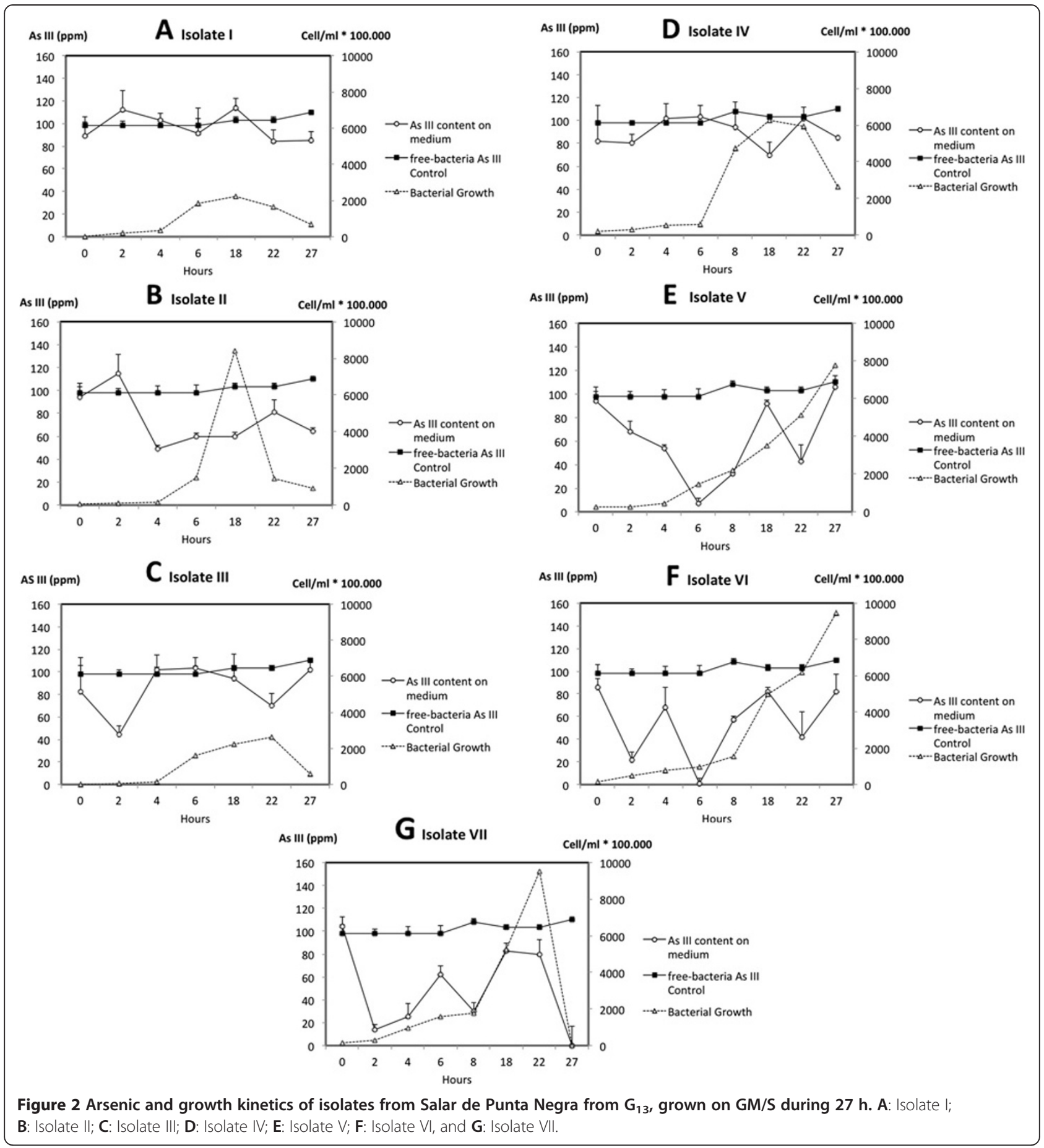

and at $27 \mathrm{~h}\left(\mathrm{t}_{27}\right)$ for isolate VII (Table 1). However, these so deep slumps in As (III) levels were not recorded in the rest of the experiment (Figure 2). Exceptionally, isolate II exhibited arsenite reduction whose magnitude remained almost constant from $t_{4}$ to $t_{27}$ (Figure 2B). Minor decreases of arsenite levels were recorded for isolates I, II, III and IV (Figure 2, A to D).
Though no clear correspondence was found between bacterial growth and arsenite decrements in the culture medium, for clones showing the largest arsenite reductions, these occurred during lag phase of growth (Figure 2, E, and $F$ in the interval $t_{0}-t_{6}$ and Figure $2 G$ in the interval $t_{0}-t_{2}$ ). It is also observed that for isolates II, IV, V, VI, and VII, bacterial growth and arsenite variation follow parallel 


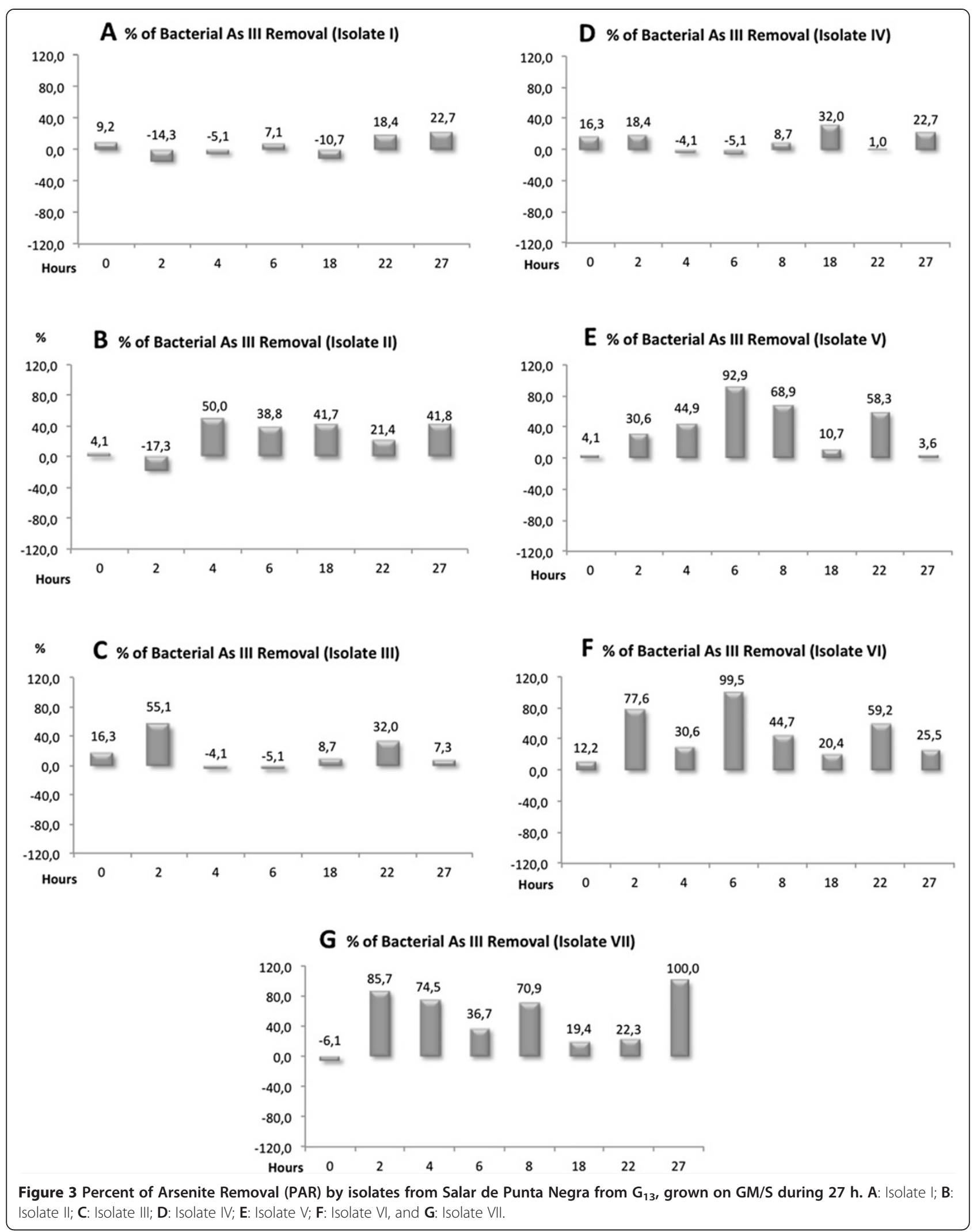


Table 1 Discrete values of as (iii) for kinetic analysis and validation results for as (iii) method

\begin{tabular}{|c|c|c|c|c|c|c|c|c|}
\hline \multicolumn{9}{|c|}{ As (III) values for treatments and controls (Average for 3 replicates $+/-$ Standard Desviation) } \\
\hline$t_{n}$ (hours) & $t_{0}$ & $t_{2}$ & $\mathbf{t}_{4}$ & $t_{6}$ & $t_{8}$ & $t_{18}$ & $t_{22}$ & $t_{27}$ \\
\hline Isolate I & $89 \pm 12.0$ & $112 \pm 17.1$ & $103 \pm 6.0$ & $91 \pm 23.0$ & NRD & $114 \pm 8.0$ & $84 \pm 10.0$ & $85 \pm 8.1$ \\
\hline Isolate || & $94 \pm 9.0$ & $115 \pm 16.2$ & $49 \pm 2.8$ & $60 \pm 2.4$ & NRD & $60 \pm 3.6$ & $81 \pm 11.1$ & $64 \pm 3.0$ \\
\hline |solate I|| & $82 \pm 31$ & $44 \pm 7.9$ & $102 \pm 13.0$ & $103 \pm 10.0$ & NRD & $94 \pm 22.0$ & $70 \pm 11.0$ & $102 \pm 9.6$ \\
\hline Isolate IV & $82 \pm 6.7$ & $80 \pm 12.0$ & $102 \pm 8.3$ & $103 \pm 8.0$ & $94 \pm 7.6$ & $70 \pm 11.5$ & $102 \pm 16.4$ & $85 \pm 8.1$ \\
\hline Isolate V & $94 \pm 8.3$ & $68 \pm 8.7$ & $54 \pm 2.5$ & $7 \pm 4.3$ & $32 \pm 1.1$ & $92 \pm 2.6$ & $43 \pm 14.0$ & $106 \pm 9.8$ \\
\hline Isolate VI & $86 \pm 7.8$ & $22 \pm 6.3$ & $68 \pm 18.0$ & $0.52 \pm 5.1$ & $57 \pm 3.3$ & $82 \pm 3.9$ & $42 \pm 22.0$ & $82 \pm 15.1$ \\
\hline Isolate VII & $104 \pm 8.3$ & $14 \pm 4.5$ & $25 \pm 12.1$ & $62 \pm 8.0$ & $30 \pm 7.7$ & $83 \pm 6.6$ & $80 \pm 12.6$ & $0.001 \pm 17.1$ \\
\hline Free-bacteria Control & $98 \pm 8.0$ & $98 \pm 4.0$ & $98 \pm 6.0$ & $98 \pm 6.7$ & $108 \pm 3.0$ & $103 \pm 3.0$ & $103 \pm 3.0$ & $110 \pm 0.6$ \\
\hline \multicolumn{9}{|c|}{ Data and Validation analysis for control replicates (free-bacteria control) } \\
\hline Average & 102 & & & & & & & \\
\hline Standard Deviation & 5.0 & & & & & & & \\
\hline$r$ limit & 12.7546070 & & & & & & & \\
\hline R limit & 14.289778 & & & & & & & \\
\hline Detection limit & 0.001 & & & & & & & \\
\hline
\end{tabular}

All values are expressed in ppm; NRD: Non-reliable data were obtained for this incubation time.

trends between $t_{22}$ and $t_{27}$ (Figure 2, B, D, E, F, and G); while for isolates I and III, trends follow opposite directions in the same time interval (Figure 2, A and C) as well as for clone IV between $t_{6}-t_{8}$.

Data did not show significant arsenite variations in the free-bacterial control over the whole analysis period, showing an arsenite concentration average of $102 \pm 5$ ppm (Table 1). On the other hand, validation criteria applied to the arsenite measurements of free-bacteria controls indicated that data are repeatable and reproducible as they comply with the limits of Repeatability ( $r$ ) and Reproducibility $(\mathrm{R})$ between series. Thus, results do not show a difference greater than $12.754 \mathrm{ppb}$ and $14.289 \mathrm{ppb}$, respectively (Table 1 ).

Percentage of Arsenite Removal: Figure 3 (A to G) shows the arsenite kinetics presented as Percentage of Arsenite Removed (PAR) from the culture media versus incubation time. The range of variation for PARs fluctuated between negative values to approximately $100 \%$. These negative PAR values of PARs estimated for isolates I, II, III, IV, and VI correspond to a calculation artefact based on the dispersion arsenite values themselves, which in some cases showed higher mean values at some $t_{n}$ than at $t_{0}$. For example, isolate I had a higher value in $t_{0}$ than at $t_{2}$ (Table 1), but the former showed a high standard deviation, so that its value could also be equal to or less than $t_{0}$.

On an average, the highest values of PARs were detected in the cultures of isolates V, VI, and VII. However, it is noteworthy that there was a high variability over time (Figure 3). Notoriously, isolate $\mathrm{V}$ showed a steady increase in PAR values between $t_{0}$ and $t_{6}$ (Figure 3 ). Furthermore, although isolate II showed low PARs, values remained relatively stable between $t_{4}$ and $t_{27}$ (Figure 3 ). Isolate VII presented a maximum PAR value of $100 \%$ at $t_{27}$. Though PAR values should be zero at $t_{0}$, they fluctuate between -6 and +16 . So, all PAR values at Figure 3 should be subjected to such variation. In fact, PAR values show standard deviations around $12 \%$.

Arsenite Oxidase and Protein Analysis: Dot Blot performed with lysates of $\mathrm{G}_{13}$-bacterial treatments, cultured with and without $\mathrm{NaAsO}_{2}$ (Figure 4A), revealed that there was antibody recognition for arsenite oxidase in all cases. This means that the expression of the enzyme in the halobacterium is not necessarily induced by the presence of arsenite in the growth medium. Figure 4B shows a similar dot-pixel analysis as a function of protein concentration for the different isolate treatments for, i.e., with and without arsenite. An exception is made for isolate IV which showed a higher expression when grew in GM/S and a low expression in GM/NS (Figure 4B). This means that arsenite seems not to influence the arsenite oxidase expression relative to total protein concentration (pixels/ $\mu$ g proteins). Figure $4 \mathrm{~B}$ also shows that arsenite oxidase concentrations are the lowest for isolates V, VI, and VII, showing the highest average arsenite removals. It is worth noting that those values were taken at $t_{18}$, when the As III values were high for this isolates. In relation to controls, a positive antibody recognition with lysates of $A$. tumefaciens C58/ATCC 33970 (Figure $4 \mathrm{C}, \mathrm{v}$ ) and with arsenite-oxidase purified from Alcaligenes faecalis NCIB 8687 (Figure 4C, iv) was obtained, whereas there was no recognition with control medium (iii). Moreover, Figure 4 shows that there was 


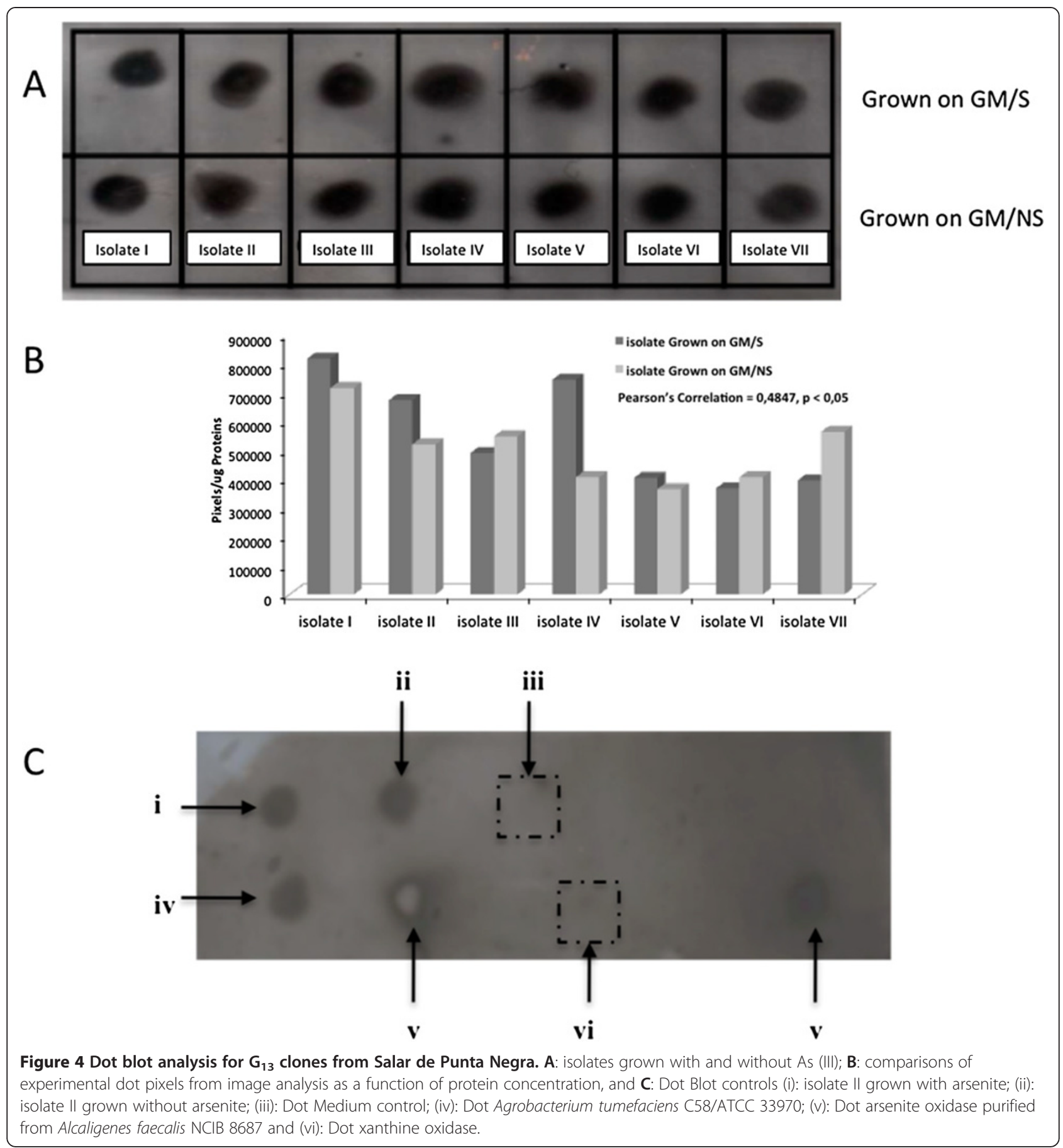

no cross-reaction with purified enzyme xanthine oxidase (vi), the result thus revealing the specific presence of arsenite oxidase in the lysates from Salar de Punta Negra.

\section{Discussion}

Isolation and Bacterial Growth: The similar number and type of colonies grown on isolation media, both with and without arsenite (IM and CIM, respectively), seem to indicate an adequate adaptation of isolated bacterial populations to a medium containing arsenite, despite the high toxicity induced in the medium. This adaptation could be facilitated by the fact that the isolation media was prepared with steril water from Salar de Punta Negra in order to keep the complex salt balance of the collection site [14]. Thus, the ionic balance of Andean saline lakes is an additional restriction for attaining biodiversity in laboratory cultures since this aspect is essential for the development 
Table 2 Culture media composition

\begin{tabular}{|c|c|c|c|c|}
\hline $\begin{array}{l}\text { Isolation Media } \\
\text { (IM) }\end{array}$ & $\begin{array}{l}\text { Control Isolation Media } \\
\text { (CIM) }\end{array}$ & $\begin{array}{l}\text { Growth Media } \\
\text { suplemented with As } \\
\text { (GM/S) }\end{array}$ & $\begin{array}{l}\text { Growth Media } \\
\text { non-suplemented with As } \\
\text { (GM/NS) }\end{array}$ & $\begin{array}{l}\text { Luria Media } \\
\text { (LM) }\end{array}$ \\
\hline - Nutritive Agar & - Nutritive Agar & -Peptone Broth & -Peptone Broth & - Tryptone \\
\hline (DIFCO). & (DIFCO). & (DIFCO). & (DIFCO). & -Yeast extract \\
\hline $\begin{array}{l}\text { - Collection site water filtered } \\
\text { through } 0.2 \text { um }\end{array}$ & $\begin{array}{l}\text { - Collection site water filtered } \\
\text { through } 0.2 \text { um }\end{array}$ & -Sterilized Milli-Q Water & -Sterilized Milli-Q Water & $-\mathrm{NaCl} 0,1 \mathrm{M}$ \\
\hline - $\mathrm{NaAsO}_{2} 100$ ppm & $-\mathrm{pH}=7,0$ & - $\mathrm{NaAsO}_{2} 100$ ppm & $-\mathrm{pH}=7,0$ & $\begin{array}{l}\text { - } \mathrm{NaOH} 2 \mathrm{M} \text { to adjustment } \\
\mathrm{pH} \text { at } 7,0\end{array}$ \\
\hline \multirow[t]{2}{*}{$-\mathrm{pH}=7,0$} & & $-\mathrm{pH}=7,0$ & & - Sterilized Milli-Q Water \\
\hline & & & & - $\mathrm{NaAsO}_{2} 100$ ppm. \\
\hline
\end{tabular}

of halophylic microbial communities, such as Salar de Punta Negra, an issue that remains poorly studied.

Considering bacterial adaptation to As III, the presence of elongated bacteroids could indicate a cellular response to metabolic stress generated by exposure to arsenic. This result is consistent with those described by different authors [15-19], relative to heavy metals inhibiting the cleavage of the bacterial cell wall, without discontinuing other processes such as growth of the same wall, growth of the cell membrane, and synthesis of individual cellular components.

Arsenic and Bacterial Growth Kinetics: Clearly, bacteria isolated from Salar de Punta Negra were able to grow with high $\mathrm{NaAsO}_{2}$ values. Furthermore, bacteria growth was associated with a decrease of As (III) in the medium in some cases, even though this reduction did not remain over time, as revealed by the bacterial growth kinetics examined in this study. In addition, no reductions of arsenite levels in free-bacterial controls indicate that bacteria produced real decrements of this element in the media. It is important to highlight that the neutral $\mathrm{pH}$ conditions of the media (Table 2) could not promote chemical transformation between different arsenic oxidation states, despite the spontaneous transformation of As (III) into As (V) under aerobic conditions predicted in the theory [20,21].

The variations observed in the arsenite levels of bacterial cultures could indicate the existence of oxidation-reduction and biosorption-biodesorption mechanisms of arsenic occurring simultaneously, as described by Silver and Phung (2005) [22]. Here, the authors refer to reports describing a broad diversity of microbes able either to reduce arsenate or to oxidize arsenite, through co-functioning of the arsenite oxidase and arsenate reductase membranous enzymatic systems [23-26]. Although there is no consensus on which of the variables triggers the prevalence of one mechanism over the other, some of the variables described as key to explain the changes in arsenic metabolism would be $\mathrm{pH}$ [27], oxygen concentrations [25], and carbon sources and temperature, among others [27], inducing the expression of genes associated with arsenic metabolism [28]. Even though the coexistence of arsenite-oxidizing and arsenate-reducing bacteria [29] would be considered as a difficulty to implement biorremediation, specific protocols to stimulate the predominance of oxidizing processes, like the maintenance of aerobic and neutral $\mathrm{pH}$ conditions in the environment surrounding the bacteria, suggest ways to achieve stable arsenite removal via microbial arsenite oxidation over time.

Arsenite Oxidase Detection Essays: Dot blot analysis showed the presence of arsenite oxidase in both arsenicbaited bacteria and arsenic non-baited bacteria. Indeed, kinetic essays showed arsenite reductions starting early, during the lag phase of bacterial growth, which is an indicator that arsenite oxidase is constitutively expressed by Salar de Punta Negra bacterial isolates. This was observed in 5 out of 7 cases (See Figure 2). There are few cases reported for this condition since, in most cases, arsenite is required in the growth medium for arsenite oxidase gene expression [30,31]. Thiomonas sp. str. 3As; Agrobacterium tumefaciens str. 5As and the microbial biofilm GM1 (isolated from arsenite-containing acid mined drainage waters of Giant Mine in Canada) also express the arsenite oxidase when the organisms are growing in the absence of arsenite, but in all of these cases, the expression does not occur before the logarithmic phase [32-34]. As mentioned above, for most clones in this study the arsenite oxidase activity was detected in the lag phase, removing As (III) medium up to $99 \%$. The explanation for expressing the enzyme earlier by isolates can be as complex as the genetic regulatory mechanisms recently described for A. tumefaciens strains involving As (III) sensing, components of signal transduction, and quorum sensing [33].

\section{Conclusions}

This paper gives evidence of arsenite oxidation by bacteria present in a High-Andean hypersaline ecosystem (arsenite-oxidizing strains have also been reported in the coastal territory in northern Chile [12]). The studied sampling site, Salar de Punta Negra, is an extreme 
environment regarding arsenic concentrations, which reach values as high as $10 \mathrm{mM}$ in current and underground waters [14]. Arsenite oxidizers were isolated from hypersaline sediments and a group of halofilic bacteria with different arsenite bioremediation potential was found. Thus, 3 arsenite-oxidizing isolates (V, VI, and VII) were able to grow, removing nearly $100 \%$ initial arsenite in the medium, but displaying a high variability of this capability over the culture time. Another isolate (II) was capable of removing about $40 \%$ inicial arsenite during its logarithmic phase, exhibiting a notable stability of its capacity over time. In all these cases the arsenite oxidase was constitutively expressed.

Studies show that halobacteria from Salar de Punta Negra exhibit promising properties as arsenite removers under control conditions, where incubation time is a critical parameter and, particularly, in those situations where in-situ arsenite removal is needed.

\section{Methods}

Description of Sampling Site: Salar de Punta Negra is a $250 \mathrm{Km}^{2}$ athalassohaline wetland located in the Atacama Desert, northern Chile ( $24^{\circ} 28^{\prime} \mathrm{S}, 69^{\circ} 53^{\prime} \mathrm{W}$, at 2,976 m. a.s.l.). It consists of several temporary saline lagoons covering about $3 \mathrm{Km}^{2}$. Mining activities occurring around this place obtain most of the water for their processes from the groundwater below the salt flat through a network of extraction wells. The geographic and climatic characteristics of the Salar together with their chemical composition provide ideal conditions for the growth of extreme microorganisms, such as bacteria, archaea, and microalgae [35], which are the trophic bases of a unique aquatic flora and fauna (microalgae, microcrustaceae, rotifers, and flamingos). Water and sediment samples from 2 lagoons located in the eastern border of the Salar were collected using sterile spatulas and sterile plastic receptacles. Samples were transported in cooler boxers and processed immediately at the Biochemistry Laboratory of Universidad Católica del Norte.

Growth Media and Bacterial Isolation: Samples from the Salar were incubated in different media with and without sodium meta-arsenite $\left(\mathrm{NaAsO}_{2}\right)$ in order to isolate and grow microorganisms. These media and their composition were named as Isolation Media (IM), Control Isolation Media (CIM), Growth Media Supplemented with As III (GM/S), and Growth Media Non Supplemented with As III (GM/NS), respectively, as shown in Table 2. A strain of Agrobacterium tumefaciens C58/ATCC 33970 was cultured in Luria broth and employed as positive control for arsenite oxidase detection. It was named Luria Media (LM). In order to promote the adaptation of isolated microorganisms and obtain a representative fraction of the microbial biodiversity in each sample, the isolation medium was prepared with sterile-filtered water from
Salar de Punta Negra (SWS). This was done so as to make bacterial growth possible and maintain the chemical equilibrium present in the water from Salar de Punta Negra in these media. Thus, the nutritive agar (DIFCO) was dissolved in a minimal milli-Q water volume sterilized at $121^{\circ} \mathrm{C} / 1$ atm. Then, the volume was completed with SWS at $60^{\circ} \mathrm{C}$. Table 2 shows the details of media composition. To obtain GM/S and GM/NS, growth media were prepared with a basis of Peptone Broth (DIFCO) supplemented and non-supplemented with $\mathrm{NaAsO}_{2} \mathrm{H}_{2} \mathrm{O}$ (Merk), respectively. For GM/S preparation a sterile-filtered $\mathrm{NaAsO}_{2} \mathrm{H}_{2} \mathrm{O}$ solution was added at $60^{\circ} \mathrm{C}$, after autoclaving the media. The resulting concentration in the GM/S was $100 \mathrm{ppm}$ in As III, prepared from a stock solution of $\mathrm{NaAsO}_{2} \mathrm{H}_{2} \mathrm{O} 200 \mathrm{ppm}$.

Given the pKa of $\mathrm{As}(\mathrm{OH})_{3}$ (9.3) and the neutral pH of culture media, this compound dissociates according to equation 1 , with an oxidation state $3+$ :

$$
\mathrm{NaAsO}_{2}+\mathrm{H}_{2} \mathrm{O} \rightarrow \mathrm{Na}^{+}{ }_{(\mathrm{aq})}+\mathrm{H}_{2} \mathrm{AsO}_{3}{ }^{-} \text {(aq) }
$$

A mixture of surface sediments and water from Salar de Punta Negra was diluted in SWS in a 1:1000 ratio. This diluted mixture was named as dilute sample. Ten plates containing IM were inoculated with $1 \mathrm{~mL}$ of the previous dilute sample and incubated at $30^{\circ} \mathrm{C}$ until the presence of colonies, named here as "generation zero" $\left(G_{0}\right)$, was verified. Then, colonies from this generation, with different morphology (color, edge, and height), were transferred to plates with $\mathrm{GM} / \mathrm{S}$ and incubated at $30^{\circ} \mathrm{C}$ for 18 to $24 \mathrm{~h}$. The colonies obtained in this step were named as $G_{1}$ and compared with the colonies of $G_{0}$, through a Gram test. To increase the biomass required for the next experiments, colonies from $G_{1}$ were transferred to flasks with $200 \mathrm{~mL}$ of $\mathrm{GM} / \mathrm{S}$ until obtaining a new bacteria generation $\left(\mathrm{G}_{2}\right)$.

Molecular Identification of Isolates: In order to determine the genomic variability between bacterial colonies, a restriction fragment length polymorphism analysis (RFLP) was conducted. Genomic DNA from isolates were obtained by Power Soil DNA isolation Kit (MoBio Laboratories Inc., Solana Beach, CA, US) and amplified by PCR. 16S rRNA genes were amplified using the primer pairs specific for Bacteria 8F ( $5^{\prime}$ AGAGTTTGATCC TGGCTCAG $3^{\prime}$ ) and 1392R ( $5^{\prime}$ ACGGGCGGTGTG TAC $3^{\prime}$ ), using $10 \mathrm{ng}$ of DNA as a template in each amplification reaction. PCR conditions were selected as previously described by Norton et al. (2008) [35]. About $\sim 1,500$ bp amplicons were digested with HhaI and MspI restriction enzymes in separated reactions for $3 \mathrm{~h}$ at $37^{\circ} \mathrm{C}$. Restriction patterns were compared by electrophoresis in $2 \%$ agarose gel and stained with etidium bromide.

Generational Cultures: To determine both, the presence of the arsenite-oxidase enzyme in bacterial lysates and if it 
was inducible in the presence of As (III), clones selected by RFLP analysis were cultured for several generations in media with and without $\mathrm{NaAsO}_{2}$. Thus, bacterial pellets of each of the seven isolates selected from $\mathrm{G}_{2}(10 \mu \mathrm{L})$ were inoculated in $200 \mathrm{~mL}$ of GM/S and GM/NS media (Table 2) and incubated for $18 \mathrm{~h}$ at $30^{\circ} \mathrm{C}$ to increase the biomass $\left(G_{3}\right)$. This procedure was repeated 10 times for each isolate to reach generation number $13^{\text {th }}$ or $\mathrm{G}_{13}$. At the same time, the reference strain of Agrobacterium tumefaciens C58/ATCC 33970 was grown in LM, according to the protocol described above (Table 2). This bacterium was used for the Dot Blot experiments as a positive control for the expression of arsenite oxidase [36]. Finally, Bradford Analysis [37] was performed for total protein quantification from each isolate of $\mathrm{G}_{13}$.

Arsenic Kinetic Experiments: In order to determine the correlation between bacterial growth and As (III) removal from the culture media, the kinetics of 7 isolates from $G_{13}$ was performed in separate experiments. Thus, $10 \mu \mathrm{L}$ of pellets from each bacterial isolate were inoculated in screw cap tubes with $15 \mathrm{~mL}$ of GM/S and incubated at $30^{\circ} \mathrm{C}$ for $18 \mathrm{~h}$. Once bacterial growth was obtained, $100 \mu \mathrm{L}$ of bacterial inoculation were transferred to Erlenmeyer flasks containing $200 \mathrm{~mL}$ of $\mathrm{GM} / \mathrm{S}$ and incubated at $30^{\circ} \mathrm{C}$, while stirring at $300 \mathrm{rpm}$ for $36 \mathrm{~h}$. Medium controls consisting of $200 \mathrm{~mL}$ noninoculated GM/S were incubated together with the previous experimental treatment flasks under the experimental conditions above to monitor the concentration of As (III) in the supernatants of the treatment flasks, relative to the total As. The latter is represented by arsenite concentration in the control medium since it does not suffer any significant change during the experiments.

As (III) in the culture medium of each treatment flask and the medium control were measured after bacteria removal, at specific incubation times: $t_{0}, t_{2}, t_{4}, t_{6}, t_{8}, t_{18}$, $t_{22}, t_{27}, t_{30}$, and $t_{36}$. To do this, $10 \mathrm{~mL}$ from each culture flask were filtered through sterile disposable filters of $0.22 \mu \mathrm{m}$ pore. The filtered-recovered medium was used for arsenic measurements. The same procedure was used for the control culture flasks. Both, treatment and control flasks, were analyzed in triplicate. Simultaneously with arsenic measurements, nonfiltered samples from the treatment flasks were used to estimate bacterial density. For this purpose, the samples were fixed in buffered glutaraldehyde (2\% glutaraldehyde solution in $0.05 \mathrm{M}$ phosphate buffer at $\mathrm{pH}$ 7.2-7.4) and cell counts were determined by the Neubauer chambers technique.

The arsenite removal capabilities of bacteria were expressed as Percentage of Arsenite Removal (PAR) and calculated from the initial values of As (III) present in the culture media $\left(t_{0}\right)$ and their corresponding values at each incubation time.
Arsenite/Total-Arsenic Quantification: Total-As and As (III) measurements were carried out by hydride-generation flow-injection atomic absorption spectrophotometry (FIAS-HG-AAS) with a detection limit of $0.001 \mathrm{ppm}$. This is a suitable method for the analysis of arsenic in waters, and it is used in most laboratories because of its high sensitivity, speed of analysis, and comparatively low cost [38,39]. A basic validation analysis was applied to the data by calculating Reproducibility and Repeatability limits [40].

Arsenite Oxidase Dot Blot Analysis: A dot blot analysis was conducted for arsenite oxidase detection. Bacterial pellets of $G_{13}$ at exponential growth phase were re-suspended in $4 \mathrm{~mL}$ of sterilized Milli- $\mathrm{Q}$ Water and lysed by sonication $(140 \mathrm{~Hz})$ with 330 -s cycles on ice. Once the bacterial pellets were lysated, suspensions were transferred to $10 \mathrm{~mL}$ sterilized tubes. Then, $20 \mu \mathrm{L}$ of $3 \mathrm{dif}-$ ferent protease inhibitors were added: aprotin $(1 \mathrm{mg} / \mathrm{mL})$; leupeptine $(1 \mathrm{mg} / \mathrm{mL})$; and PMSF/DMSO (100 mM). Five $\mu \mathrm{L}$ of each lysated were put on a nitrate-cellulose membrane (pore size of $0.47 \mathrm{~mm}$ Millipore). To check the specificity of antibodies and prevent cross reactivity, another $5 \mu \mathrm{L}$ of bovine xantine oxidase (another molibdopterin protein) from bovine milk, Sigma - Aldrich diluted in 1:50, were dotted on the same membrane. This enzyme was chosen because it exhibits a high structural similarity with arsenite oxydase [14]. Arsenite oxydase purified from A. faecalis NCBI 8687 (792 Ao, $55 \mu \mathrm{M})$ [6], provided by Dr. Gretchen Anderson (Department of Chemistry, Indiana University, South Bend in USA), and lysates of $A$. tumefaciens C58/ATCC 33970 were used as positive controls of AOX expression. Sterilized GM/S was used as negative control for the same purpose. The membrane was blocked with $6 \%$ non-fat milk in TBS $(0.1 \%$ Tween 20) (TBS-T) for $2 \mathrm{~h}$ at room temperature. To detect the arsenite oxidase, the membrane was incubated overnight at $4^{\circ} \mathrm{C}$ with diluted 1:25 in PBS-T polyclonal rabbit anti $A$. faecalis AOX primary antibody (793 ARs, $100 \mu \mathrm{g} / \mathrm{ml}$ ), also provided by Dr. Gretchen Anderson. Then, the membrane was washed 3 times with TBS-T and incubated with 0.2 $\mu \mathrm{g} / \mathrm{mL}$ HRP-conjugated goat anti-rabbit IgG for $1.5 \mathrm{~h}$. They it was washed again and revealed with Pierce ECL Substrate and GE Healthcare ECL Reagent prepared according to the manufacturer's instructions.

Both microbiological and physicochemical assays of the present study were carried out following security protocols normalized in the Laboratorio de Servicios Analíticos (LSA) at the Universidad Católica del Norte wich has the ISO/IEC 17025 accreditation [41].

\section{Abbreviations}

PAR: Percentage of arsenite removal; IM: Isolation medium; CIM: Control isolation medium; GM/S: Growth media supplemented with arsenite; GM/NS: Growth media non supplemented with arsenite; LM: Luria medium; $G_{n}$ : Generation n; $t_{n}$ : Time $n$; SWS: Sterile-filtered water of salar de punta negra. 


\section{Competing interests}

No competing interests are involved in this work.

\section{Authors' contribution}

D-PP: Conceived the study and participated in its design and coordination. She also wrote the core of the manuscript. GA; PS, and GR: They conducted the microbiological analysis and the As kinetics. They participated as undergraduate students. MH: She conducted the molecular genetic studies for clone identification, RFLP analysis and helped write the manuscript draft. PP: She coordinated the dot blot analysis and helped write the manuscript draft. SS, FQ, and CC: She coordinated the As Analysis and validation methods for As data. DA and KG: They conducted the Dot Blot analysis. All authors read and approved the final manuscript.

\section{Authors' information}

The main author, D-PP, has always worked in environmental microbiology concerning saline environments of arid zones in Chile and Spain. In the last few years, she has been part of a research group including analytical chemists (GA, SS, CF), physical chemists (CC), and biochemists (PP and $M H)$, who have been studying stress factors affecting the biological communities of Chilean and Peruvian Highlands (heavy metals, phytochelantins, etc.). Together with Doctors SS, FQ, and DC, she is part of the research group at UCN Analytical Services Laboratory, the only testing lab accredited by ISO 17,025 in northern Chile. In addition, Dr. FQ is the president of the Analytical Chemistry Division of the Chilean Chemical Society. All students, DA, KG, GR, and PS, who participated in this study, prepared their undergraduate and graduate theses.

\section{Acknowledgments}

This study was supported by grants from AECI A/6429/06 Project. The authors are grateful to Dr. Gretchen Anderson from the Department of Chemistry, Indiana University, South Bend in the USA, for his kind donation of biological reagents for inmuno-essays.

\section{Author details}

'Departamento de Química, Facultad de Ciencias, Universidad Católica del Norte, P.O.1280, Antofagasta, Chile. ${ }^{2}$ Advanced Mining Technology Center, AMTC, Universidad de Chile, Tupper 2007, Santiago, Chile. ${ }^{3}$ Laboratorio de Complejidad Microbiana y Ecología Funcional, Facultad de Recursos del Mar \& Centro de Biolnnovación de Antofagasta, Universidad de Antofagasta, Antofagasta, Chile.

Received: 17 July 2012 Accepted: 21 February 2013 Published: 1 April 2013

\section{References}

1. Dibner B: Agricola on metals. Norwalk, CT: Burndy Library; 1958.

2. World Health Organization: Environmental Health Criteria 224 Report: Arsenic and arsenic compounds. Secondth edition. Geneva; 2001.

3. Hunter D: The Diseases of Ocupation. London: English Universities Press Ltd 1969.

4. Bissen M, Frimmel FH: Arsenic-a review part I: occurrence, toxicity, speciation, mobility. Acta Hydrochimica et Hydrobiologica 2003, 31:9-18

5. Simeonova DD, Micheva K, Muller DA, Lagarde F, Lett MC, Groudeva VI, Lièvremont $D$ : Arsenite oxidation in batch reactors with alginateimmobilized ULPAs1 strain. Biotechnol Bioeng 2005, 91:441-446.

6. Anderson $G$, Williams J, Hilles R: The purification and characterization of arsenite oxidase from Alcaligenes faecalis, a molybdenum-containing hydroxylase. J Biol Chem 1992, 267:23674-23682.

7. Conrads T, Ellis P, Hille R, Kuhn P: Cristal structure of the $100 \mathrm{kDa}$ arsenite oxidase from Alcaligenes faecalis in two crystal forms at $1.64 \AA$ and 2,03 Å. Elsevier Sci Rev 2001, 9:125-132.

8. Ehrlich L: Bacterial oxidation of As (III) compounds. In Environmental Chemistry of Arsenic. Edited by Frankenberger Jr WT. New York: Marcel Dekker; 2001:313-328.

9. Lebrun E, Brugna M, Bayman F, Muller D, Lièvremont D, Lett M, Nitschke W: Arsenite oxidase, an ancient bioenergetic enzyme. Mol Biol Evol 2003, 20:686-693.

10. Oremland S, Hoeft S, Santini J, Bano N, Hollibaugh R, Hollibaugh J: Anaerobic oxidation of arsenite in mono lake water and by a facultative, arsenite-oxidizing chemoautotroph, strain MLHE-1. Environ Microbiol Rev 2002, 68:4.795-4.802
11. Wildfang E, Healy S, Aposhian H: Arsenic. In Molecular biology and toxicology of metals. Edited by Zalups RK, Koropatnick DJ. London: Taylor and Francis; 2000:75-112.

12. Valenzuela C, Campos VL, Yañez J, Zaror CA, Mondaca MA: Isolation of arseniteoxidizing bacteria from arsenic-enriched sediments from Camarones river, Northern Chile. Bull Environ Contam Toxicol 2009, 82:593-596.

13. Lizama C, Monteoliva-Sanchez M, Prado B, Ramos-Cormenzana A, Weckesser J, Campos V: Taxonomic study of extreme halophilic archaea isolated from the "Salar de Atacama", Chile. Syst Appl Microbiol 2001, 24:464-474.

14. Risarcher F: The origin of brines and salts in Chilean salars: a hydrochemical review. Elsevier Sci Rev 2003, 63:249-293.

15. Sobolev D, Begonia MFT: Effects of heavy metal contamination upon soil microbes: lead-induced changes in general and denitrifying microbial communities as evidenced by molecular markers. Int J Environ Res Public Health 2008, 5:450-456.

16. Pumarola A: Book of Microbiology and Medical Parasitology. 2nd edition. Barcelona: Masson S.A; 1987.

17. Doelman $P$, Haanstrax L: Short-term and long-term effects of cadmium, chromium, copper, nickel, lead and zinc on soil microbial respiration in relation to abiotic soil factors. Plant Soil 1979, 79:317-327.

18. Hemida SK, Omar SA, Abdel-Mallek AY: Microbial populations and enzyme activity in soil treated with heavy metals. Water Air Soil Pollut 1997 95:13-22.

19. Bianchini A, Playle RC, Wood CM, Walsh PJ: Mechanism of acute silver toxicity in marine invertebrates. Aquat Toxicol 2005, 72:67-82.

20. (AWWA) American Water Works Association: Water Quality and Treatment. 4th edition. Denver: American Water Works Association; 1990

21. Morel F, Hering J: Principles and Applications of Aquatic Chemistry. New York, USA: John Wiley \& Sons Inc:; 1993.

22. Silver S, Phung LT: Genes and enzymes involved in bacterial oxidation and reduction of inorganic arsenic. Appl Environ Microbiol 2005, 71:599-608.

23. Inskeep WP, McDermott TR, Fendorf S: Arsenic (V)/(III) cycling in soils and natural waters. In Environmental Chemistry of Arsenic. Edited by Frankenberger WT Jr. New York: Marcel Dekker; 2001:183-215.

24. Macy JM, Santini JM: Unique modes of arsenate respiration by Chrysiogenes arsenates and Desulfomicrobium sp. str. Ben- $\mathrm{R}$, sp. str. Ben-RB. In Environmental Chemistry of Arsenic. Edited by Frankenberger WT Jr. New York: Marcel Dekker; 2001:279-312.

25. Oremland R, Stolz JF: The ecology of arsenic. Science 2003, 300:939-934

26. vanden Hoven RN, Santini JM: Arsenite oxidation by the heterotroph Hydrogenophaga sp. str. NT-14: the arsenite oxidase and its physiological electron acceptor. Biochim Biophys Acta 2004, 1656:148-155.

27. Turner AW: Bacterial oxidation of arsenite. Nature 1949, 164:76-77.

28. Phillips S, Taylor M: Oxidation of arsenite to arsenate by Alcaligenes faecalis. Appl Environ Microbiol 1976, 32:392-399.

29. Richey C, Chovanec P, Hoeft S, Oremland RS, Basu P, Stolz JF: Respiratory arsenate reductase as a bidirectional enzyme. Biochem Biophys Res Commun 2009, 382:298-302

30. Hoeft SE, Switzer Blum J, Stolz JF, Tabita FR, Witte B, King GM, Santini JM, Oremland RS: Alkalilimnicola ehrlichii sp. nov., a novel arsenite-oxidizing haloalkaliphilic gamma proteobacterium capable of chemoautotrophic or heterotrophic growth with nitrate or oxygen as the electron acceptor. Int J Syst Evol Microbiol 2007, 57:504-512.

31. Stolz JF, Basu P, Santini JM, Oremland R: Arsenic and selenium in microbial metabolism. Microbiology 2006, 60:107-130.

32. Duquense K, Lieutaud A, Ratouchniak J, Muller D, Lett M, Bonnefoy V: Arsenite oxidation by a chemoautotrophic moderately acidophilic Thiomonas sp.: from the strain to gene study. Environ Microbiol 2008, 10:228-237.

33. Kashyap DR, Botero LM, Franck WL, Hassett DJ, Mc Dermott TR: Complex regulation of arsenite oxidation by Agrobacterium tumefaciens. J Bacterio/ 2006, 188:1081-1088.

34. Osborne TH, Jamieson HE, Hudson-Edwards KA, Nordstrom DK, Walker SR, Ward SA, Santini JM: Microbial oxidation of arsenite in a subarctic environment: diversity of arsenite oxidase genes and identification of a psychrotolerant arsenite oxidizer. BMC Microbiol 2005, 10:205.

35. Norton GJ, Duan G, Dasgupta T, Islam MR, Lei M, Zhu Y, Deacon CM, Moran AC, Islam S, Zhao FJ: Environmental and genetic control of arsenic accumulation and speciation in rice grain: comparing a range of common cultivars grown in contaminated sites across Bangladesh, China, and India. Environ Sci Technol 2010, 43:8381-8386. 
36. Botero L, Franck W, Hassett D, Kashyap D, McDemott T: Complex regulation of arsenic oxidation in Agrobacterium tumefaciens. J Bacteriol 2005, 188:1081-1088.

37. Bradford MM: A rapid and sensitive method for the quantitation of microgram quantities of protein utilizing the principle of protein-dye binding. Anal Biochem 1976, 72:248-254

38. Hershey JW, Oostdyk TS, Keliher PN: Determination of arsenic and selenium in environmental and agricultural samples by hydride generation atomic absorption spectrometry. J Assoc Off Anal Chem 1988, 71:1090-1093.

39. Sakamoto $H$, Susa $Y$, Ishiyama $H$, Tomiyasu $T$, Anazawa $K$ : Determination of trace amounts of total arsenic in environmental samples by hydride generation flow injection-AAS using a mixed acid as a pretreatment agent. Analyt Sci 2001, 17:1067-1071.

40. Maroto A, Riu J, Boqué R, Rius F: Estimating uncertainties of analytical results using information from the validation process. Analytical Chimica Acta 1999, 391:173-185.

41. International Organization for Standardization and International Electrotechnical Commission Conformity assessment: General requirements for the competence of testing and calibration laboratories. Geneva: ISO; 2005 ISO/IEC 17025

doi:10.1186/2046-9063-9-8

Cite this article as: Paula et al:: Kinetics of arsenite removal by halobacteria from a highland Andean Chilean Salar. Aquatic Biosystems 2013 9:8.

\section{Submit your next manuscript to BioMed Central and take full advantage of:}

- Convenient online submission

- Thorough peer review

- No space constraints or color figure charges

- Immediate publication on acceptance

- Inclusion in PubMed, CAS, Scopus and Google Scholar

- Research which is freely available for redistribution 